\title{
REKONSTRUKSI MODEL PEMBELAJARAN BAHASA ARAB DENGAN KERANGKA QUANTUM TEACHING
}

\author{
Muhammad Yusuf Salam \\ Prograam Studi Tadris Bahasa Arab, Jurusan Tarbiyah STAIN Batusangkar \\ Korespondensi: Jln. Sudirman No. 137 Kubu Rajo Lima Kaum Batusangkar, Sumatera Barat \\ e-mail: yusuf_salam@yahoo.com
}

\begin{abstract}
Quantum Teaching (QT) is a learning model developed by Bobby DePorter. QT emphasizes on the teacher skill in managing learning which facilitate the development of students' potential. The major principle of $Q T$ is 'bring their world our world and take our world into their world. To carry out the implementation of $Q T$ successfully, teachers need to consider context (environment) and content (instructional materials). In the context of Arabic learning which is constructed by means of QT, following framework: TANDUR which stands for Tumbuhkan (grow), Alami (be natural), Namai (name), Demontrasi (demonstrate), Ulangi (repeat) and Rayakan (celebrate).
\end{abstract}

Kata kunci: quantum teaching, pembelajaran, bahasa Arab

\section{PENDAHULUAN}

$\mathrm{F}$ ase perkembangan pengajaran bahasa Arab di Indonesia sekarang ini tidak hanya diajarkan di pondok-pondok pesantren saja, tetapi pembelajaran bahasa Arab juga sudah dikembangkan dalam lembaga pendidikan formal bahkan dicantumkan dalam mata pelajaran tersendiri di sekolah-sekolah. Seperti MI (Madrasah Ibtidaiyah) untuk tingkat dasar yang setara dengan SD, MTs (Madrasah Tsanawiyah) yang setara dengan SMP, MA (Madrasah Aliyah) yang setara dengan SMA dan untuk Perguruan Tinggi.

Meskipun bahasa Arab sudah masuk dalam mata pelajaran tersendiri di sekolah-sekolah atau madrasah, namun tidak semudah membalikkan telapak tangan menciptakan siswa dapat menyerap, memahami, serta menguasai materi bahasa Arab yang telah diajarkan.
Banyak permasalahan yang sering muncul dalam proses pembelajaran bahasa Arab. Di antaranya siswa merasa kesulitan dalam menyerap dan memahami, apalagi menguasai materi bahasa Arab yang telah diajarkan oleh gurunya.

Adapun permasalahan-permasalah tersebut dipengaruhi oleh beberapa faktor, di antaranya berasal dari guru yang kurang memahami arti penting penggunaan metode serta strategi yang produktif, aktif dan menyenangkan.

Seiring perkembangan zaman, dunia pendidikan juga memerlukan berbagai inovasi. Hal ini penting dilakukan untuk kemajuan kualitas pendidikan, tidak hanya pada tataran teori tapi sudah bisa diarahkan kepada hal yang bersifat praktek. Diakui atau tidak walau belum di dukung penelitian khusus tentang pembelajaran, banyak yang merasa sistem pendidikan terutama proses belajar mengajar bahasa Arab, siswa seringkali 
merasa bosan dengan suasana pembelajaran, merasa tidak dihargai kemampuannya. Bahkan banyak di antara mereka yang menganggap bahasa Arab tidak bermanfaat dalam kehidupan nyatanya.

Salah satu alternatif solusi untuk mengatasi berbagai masalah di atas, diterapkan belajar yang menyenangkan dari Bobbi de Porter (penulis buku best seller Quantum Learning dan Quantum Teaching) bisa dijadikan rujukan. Metode belajar ini diadopsi dari beberapa teori. Antara lain sugesti, teori otak kanan dan kiri, teori otak triune, pilihan modalitas (visual, auditorial, dan kinestetik) dan pendidikan holistik.

QT mencoba menjawab persoalan tersebut dengan menciptakan suasana pembelajaran yang dinamis, demokratis, menarik minat siswa dan membuat mereka merasakan pembelajaran sebagai sebuah proses yang menyenangkan dan berguna. Sehingga mereka dapat bertahan lama untuk belajar. Quantum teaching bersandar pada konsep "bawalah dunia mereka ke dunia kita, dan antarkan dunia kita ke dunia mereka". Hal ini memberi pengertian bahwa mendapatkan hak mengajar, seorang guru harus membuat jembatan autentik memasuki kehidupan siswa sebagai langkah pertama. Setelah kaitan itu terbentuk bawalah mereka ke dunia kita sehingga siswa dapat membawa apa yang dipelajari ke dalam dunianya dan menerapkannya pada situasi baru (Bobbi DePoreter et.al , 2004: 4).

Model pembelajaran $Q T$ sering juga disebut dengan teknik pembelajaran modern yang sangat menekankan adanya pemberdayaan dan penghargaan yang setinggi-tingginya terhadap apapun yang dicapai oleh peserta didik. Model ini menguraikan cara-cara baru yang memudahkan proses belajar lewat pemaduan unsur seni dan pencapaianpencapaian yang terarah, apapun mata pelajaran yang diajarkan menekankan kegiatannya pada pengembangan potensi manusia secara optimal melalui caracara yang sangat manusiawi, yaitu: mu- dah, menyenangkan, dan memberdayakan. Serta dikondisikan untuk saling mempercayai dan saling mendukung.

Konsep itu sukses diterapkan di Super Camp, lembaga kursus yang dibangun de Porter. Dia melakukan sebuah penelitian untuk disertasi doktroral pada 1991, yang melibatkan sekitar 6.042 responden. Dari penelitian itu, Super Camp berhasil mendongkrak potensi psikis siswa. Antara lain 68\% meningkatkan motivasi belajar siswa, 73\% meningkatkan prestasi belajar siswa, $81 \%$ meningkatkan rasa percaya diri siswa, dan $98 \%$ melanjutkan penggunaan keterampilan siswa (Bobbi DePorter, 2000: 4).

Berdasarkan konsep $Q T$ tersebut, penulis tertarik mengkaji lebih lanjut dalam karya ilmiah yang berjudul "Rekonstruksi Pembelajaran Bahasa Arab dengan kerangka Quantum Teaching". Model ini mencoba merekonstruksi model pembelajaran bahasa Arab sebelumnya terkesan konvensional dan dirubah menjadi sistem pembelajaran yang modern.

\section{PEMBELAJARAN BAHASA ARAB}

Dalam pendekatan sistem, pembelajaran merupakan suatu kesatuan dari komponen-komponen pembelajaran yang tidak dapat dipisahkan antara satu dengan yang lain, karena satu sama lain saling mendukung. Komponen-komponen tersebut dapat menunjang kualitas pembelajaran. Komponen-komponen tersebut terdiri dari: (1) Siswa, (2) Guru, (3) Tujuan, (4) Materi, (5) Metode, (6) Sarana/Alat, (7) Evaluasi, dan (8) Lingkungan/konteks. Masing-masing komponen itu sebagai bagian yang berdiri sendiri, namun dalam berproses di kesatuan sistem mereka saling bergantung dan bersama-sama untuk mencapai tujuan. (Soetopo, 2005: 143).

Kedelapan komponen tersebut rupanya tidak ada satupun komponen yang dapat dipisahkan satu sama lain karena dapat mengakibatkan tersen- 
datnya proses belajar-mengajar. Masingmasing komponen dalam pembelajaran dapat dijelaskan sebagai berikut.

Siswa; teori didaktik metodik telah bergeser dalam menempatkan siswa sebagai komponen proses belajar mengajar (PBM). Siswa yang semula dipandang sebagai objek pendidikan bergeser sebagai subjek pendidikan. Sebagai subjek, siswa adalah kunci dari semua pelaksanaan pendidikan. tiada pendidikan tanpa anak didik. Untuk itu siswa harus dipahami dan dilayani sesuai dengan hak dan tanggung jawabnya sebagai siswa.

Siswa dianggap sebagai organisme yang beraktifitas untuk mencapai ranahranah psikologi, baik kognitif, afektif, maupun psikomotor. Dengan demikian, pembelajaran bahasa Arab pun ditujukan untuk siswa dalam mencapai dan memperoleh keterampilan berbahasa (istima', kalam, qiraah, dan kitabah) pada ranah kognitif, afektif, dan psikomotor secara utuh.

Guru; guru merupakan subjek dalam proses belajar mengajar. Peran guru yang dominan dalam proses belajar di antaranya sebagai demonstrator, pengelola kelas, mediator dan fasilitator, evaluator, maupun sebagai pembimbing (Sabri, 2010: 68-70). Peranan guru sangat menentukan keberhasilan proses belajar mengajar. Tugas utama seorang guru adalah menyusun materi pelajaran dan menyampaikannya dengan cara yang tepat. Guru yang cerdas, rajin, kreatif dan memiliki pengetahuan yang cukup tentang kondisi psikis dan lingkungan siswa akan lebih berhasil dari pada guru yang tidak peka terhadap keadaan siswanya.

Dalam pembelajaran bahasa Arab tugas utama guru bahasa Arab adalah mengembangkan kompetensi komunikasi, mengembangkan kompetensi linguistik, kompetensi personal, dan kompetensi komunikasi siswa. Kompetensi komunikasi bertujuan agar siswa berani dan mampu berkomunikasi menggunakan bahasa Arab, dengan temannya ataupun si pemilik bahasa itu sendiri (orang Arab), baik secara reseptif maupun produktif.

Keberhasilan siswa dalam proses pembelajaran bahasa Arab sangat ditentukan oleh seorang guru, oleh karena itu, kompetensi guru secara keilmuan dan metodologis menjadi faktor krusial dalam proses pembelajaran bahasa Arab. Dalam konteks keilmuan, seorang guru bahasa Arab harus benar-benar memahami dan menguasai hakikat bahasa Arab kaitannya dengan karakter bahasa Arab, kompetensi bahasa Arab, yaitu istima', kalam, qiroah dan kitabah, serta memahami dan menguasai dengan baik ilmu tata bahasa Arab, yaitu nahwu dan shorof serta ilmu-ilmu yang menjadi pelengkap dalam memahami bahasa Arab. Sedangkan dalam konteks kompetensi metodologis, seorang guru harus memahami dan memiliki kemampuan dalam menerapkan pendekatan, metode dan strategi pembelajaran bahasa Arab yang relevan dengan objek (siswa), efektif dan menyenangkan (Madkur, 1985: 36-37).

Tujuan Pembelajaran bahasa Arab; Hermawan (2008: 9.4) Tujuan pembelajaran merupakan rumusan perilaku yang telah ditetapkan sebelumnya agar tampak pada diri siswa sebagai akibat dari perbuatan belajar yang telah dilakukan. Hermawan (2008: 1.17). Tujuan yang jelas akan memberi petunjuk yang jelas terhadap pemilihan materi/bahan ajar, strategi, media, dan evaluasi.

Berkaitan dengan pembelajaran bahasa Arab secara umum memiliki tujuan agar para peserta didik berkembang dalam hal: kemampuan mendengarkan, berbicara, membaca, dan menulis bahasa Arab secara baik. Untuk mencapai tujuan ini siswa diperkaya dengan perbendaharaan kata Arab fushha sebanyak 1500 kosa kata lebih dalam berbagai bentuk 
kata dan pola kalimat yang diprogramkan meliputi tema tentang kegiatan sehari-hari, kajian keislaman. Rasionalisasi penguasaan 1500 kosa kata tersebut adalah 300 kata pada jenjang Ibtidaiyah dan 700 kata pada jenjang Tsanawiyah, serta 750 kosa kata pada jenjang Aliyah.

Pendekatan, metode dan strategi Pembelajaran Bahasa Arab; Pendekatan (approach), metode (method) dan teknik (technique) adalah tiga istilah yang mempunyai hubungan hirarkhi. Pendekatan (approach) yang dalam bahasa Arab disebut al-madkhal adalah seperangkat asumsi mengenai hakekat bahasa dan hakekat belajar bahasa. Metode (at-thariqah) adalah rencana menyeluruh yang berhubungan dengan penyajian materi pelajaran secara teratur dan tidak saling bertentangan dan didasarkan atas sesuatu approach. Technique, yang dalam bahasa Arab disebut uslub atau familiar di Indonesia disebut strategi, adalah apa yang sesungguhnya terjadi didalam kelas dan merupakan pelaksanaan dari metode (Arsyad, 2004: 19). Dalam usaha pencapaian tujuan pengajaran bahasa, yaitu untuk perolehan keterampilan bahasa Arab, maka ketiga konsep ini adalah suatu yang mesti diramu oleh pengajar.

Materi; materi merupakan pegangan guru dan siswa dalam proses pembelajaran bahasa Arab. Dengan menggunakan materi, arah pembelajaran bahasa Arab akan terarah dan jelas. Tapi jika kita amati, sampai saat ini masih banyak lembaga pendidikan yang menggunakan meteri bahasa Arab yang belum relevan dan efektif, sehingga perlu adanya revisi dan pembenahan.

Media; media adalah perantara atau pengantar pesan dari pengirim ke penerima pesan. (Salim, 1987: 1). Media pengajaran secara luas dapat diartikan sebagai berikut: setiap orang, bahan, alat atau kejadian yang memantapkan kondisi yang memungkinkan siswa memperoleh pengetahuan, keterampilan dan sikap. Media merupakan salah satu unsur urgen dalam proses pembelajaran bahasa
Arab. Fungsi media adalah sebagai alat bantu yang memudahkan guru dalam menyampaikan materi dan memudahkan siswa dalam memahami materi yang disampaikan oleh guru.

Evaluasi; komponen evaluasi ditujukan untuk menilai pencapaian tujuan yang telah ditentukan. Hasil dari kegiatan evaluasi dapat digunakan sebagai umpan balik (feedback) untuk melaksanakan perbaikan dalam kegiatan pembelajaran yang berkaitan dengan materi yang digunakan, pemilihan media, pendekatan pengajaran, dan metode dalam pembelajaran.

Evaluasi sangat penting dalam proses pembelajaran bahasa Arab. Paling tidak ada tujuh signifikannya; 1) evaluasi dalam hal ini diaplikasikan dalam bentuk placement test (tes penempatan), 2) membantu mereka memilih program/jurusan, 3) mengukur pemerolehan keterampilan siswa dalam berbahasa Arab, 4) dapat membantu lembaga pendidikan dan guru dalam mengembangan kurikulum bahasa Arab, 5) memotivasi gurusiswa untuk terus berprestasi dalam bahasa Arab, 6), membatu lembaga atau guru dalam mengambil keputusan, dan 7) menyadarkan publik signifikansi program pembelajaran bahasa Arab. (Muhbib, 2008: 312-314)

Lingkungan; keberhasilan belajar bahasa Arab sangat dipengaruhi dan ditentukan oleh lingkungan yang kondusif. Lingkungan yang dimaksud adalah lingkungan di mana siswa belajar bahasa dan dimana dia bertempat tinggal. Dengan lingkungan yang bernuansa arabiah, siswa akan termotivasi untuk belajar dan mempraktekkan bahasa Arab, sehingga pada akhirnya dia terbiasa berkomunikasi dengan bahasa Arab dalam kehidupan kesehariannya seperti menggunakan bahasa ibunya.

\section{PENGERTIAN QUANTUM TEACH- ING}

Quantum teaching terdiri dari dua kata yaitu quantum dan teaching. 
Quantum adalah interaksi yang mengubah energi menjadi cahaya. Sedangkan teaching adalah proses pembelajaran yang berarti transfer ilmu pengetahua dari guru kepada siswa. (Bobbi Deporter, 2004: 5). Menurut Ramayulis (2008: 225). pembelajaran quantum adalah pembelajaran dengan interaksi-interaksi yang mengubah energi menjadi cahaya karena semua kehidupan adalah energi. Maksud dari energi menjadi cahaya adalah mengubah semua hambatanhambatan belajar yang selama ini ditemukan dalam pembelajaran menjadi sebuah manfaat bagi siswa sendiri dan orang lain dengan memaksimalkan kemampuan dan bakat alamiah siswa. Dengan demikian quantum teaching dapat diartikan model pembelajaran yang menekankan pada pengubahan kecerdasan dan kemampuan siswa menjadi cahaya bagi diri sendiri dan bagi orang lain.

Model pembelajaran quantum pertama kali dicetuskan oleh Georgi Lazanov seorang pendidik berkebangsaan Bulgaria. Dia melakukan uji coba tentang suggesti dan pengaruhnya terhadap hasil belajar dengan teorinya suggestology yang mengatakan pada prinsipnya suggesti mempengaruhi hasil belajar. Teknik yang digunakan untuk memberikan suggesti positif diantaranya, mendudukkan siswa secara nyaman, memasang musik dalam kelas, meningkatkan partisipasi siswa, menggunakan poster dalam menyampaikan informasi, menggunakan media yang menarik perhatian siswa dan menyediakan guruguru yang berdedikasi tinggi (Udin Syaefudin Sa'ud 2009: 125)

$Q T$ selanjutnya dikembangkan oleh Bobby DePorter, dia adalah pengembang utama pembelajaran quantum (Hartono dkk 2008: 49). Dia mengembangkan pembelajaran quantum di supercamp yakni sebuah perusahaan yang memusatkan perhatian pada persoalan pembelajaran untuk mengem- bangkan potensi manusia. Metode ini dibangun berdasarkan pengalaman dan penelitian terhadap 25 ribu peserta didik dan sinergi pendapat ratusan tenaga pengajar. Menurutnya metode belajar ini sesuai dengan cara kerja otak manusia dan cara belajar manusia (Udin Syaefudin Sa'ud 2009: 125 ).

Di dalam konteks pembelajaran dapat dijelaskan bahwa di dalam tubuh anak didik terdapat energi . Energi yang dimaksud adalah energi otak, emosi, fisik dan rohani. Ketika energi internal berinterkoneksi dengan energi eksternal, lahirlah kondusivitas pembelajaran di dalam diri peserta didik. Tujuan siswa dalam belajar adalah meraih sebanyak mungkin cahaya, berupa interaksi, hubungan dan inspirasi agar menghasilkan energi cahaya untuk keperluan belajar. (Sudarwan Darmin 2003 : 219).

Pengajaran dalam bentuk $Q T$ tampak lebih komprensif, karena didalamnya terkandung berbagai metode pengajaran yang diolah menjadi satu seperti ceramah, tanya jawab, demonstrasi, karya wisata, penugasan, pemecahan masalah, diskusi, simulasi dan eksperimen. Berbagai metode satu sama lain bersinergi membentuk $Q T$. Dalam pembelajaran, $Q T$ menggunakan rancangan pembelajaran yaitu; Tumbuhkan, Alami, Namai, Demonstrasikan, Ulangi dan Rayakan yang disingkat dengan istilah TANDUR. (Bobbi DePoreter et.al 2004: 7 ). Rancangan ini dilaksanakan secara terpadu dalam kegiatan pembelajaran sehingga situasi kegiatan pembelajaran menjadi sangat aktif, dinamis dan menyenangkan dengan hasil yang memuaskan.

\section{PEMBAGIAN QUANTUM TEACH- ING}

Model $Q T$ menyajikan bentuk pembelajaran sebagai suatu orkestrasi yang terdiri dari dua unsur pokok yaitu konteks dan isi. Konteks secara umum 
menjelaskan tentang lingkungan belajar baik lingkungan pisik maupun lingkungan psikis. Sedangkan konten/ isi berkenaan dengan bagaimana isi pembelajaran dikemas untuk disampaikan kepada siswa. Berikut ini penjelasan dua bagian utama dari $Q T$ :

\section{Dari Segi Konteks}

Proses pembelajaran quantum dari segi konteks dilaksanakan dengan langkah-langkah sebagai berikut (Ramayulis 2008: 232-233)

1. Ciptakan suasana yang menggairahkan.

Guru harus menciptakan suasana belajar yang memberdayakan siswa. Hal ini dapat diwujudkan dengan menyediakan lingkungan fisik yang indah dan nyaman dan juga perlu dipersiapkan lingkungan psikis yang baik. Lingkungan psikis ini yaitu 1) Kekuatan niat dan berpandangan positif. 2) Menjalin rasa simpati dan saling pengertian. 3) Adanya keriangan, 4) Mau mengambil resiko. 5) menumbuhkan rasa saling memiliki, 6) Menunjukkan keteladanan (Udin Syaefudin Sa'ud 2009: 131 ).

2. Tentukan landasan yang kokoh serta tujuan yang ingin dicapai.

Menentukan landasan yang kokoh ini adalah dengan cara mengkomunikasikan tujuan pembelajaran, menguatkan prinsip-prinsip keunggulan, meyakini kemampuan diri dan kemampuan siswa, kebijakan, prosedur dan peraturan serta menjaga komunitas belajar tetap tumbuh dan berjalan. Intinya pembelajaran bahasa Arab harus tetap dinamis

3. Ciptakan lingkungan yang kondusif. Lingkungan pembelajaran akan mempengaruhi terhadap kemampuan siswa dalam memusatkan perhatian dan menyerap informasi. Keberhasilan belajar ditentukan berdasarkan pada pembentukan lingkungan siswa sehingga kegiatan-kegiatan siswa itu sendiri menghasilkan umpan balik yang tepat dalam menjalankan peng- ajaran yang sesungguhnya (Win Wenger 2001: 39).

Penciptaan lingkungan yang kondusif terkait dengan beberapa hal;

a. Perhatikan lingkungan sekeliling

Sebuah gambar lebih berarti dari seribu kata. Pandangan yang ada di sekeliling akan membantu daya ingat. Gambar-gambar yang berkaitan dengan teori akan memberikan kesan mendalam dalam pembelajaran. Kelas ideal adalah kelas yang dipenuhi gambar-gambar dan simbol-simbol pembelajaran yang dapat memudahkan siswa dalam belajar.

b. Gunakan media pembelajaran

Penggunaan media tidak hanya membantu pembelajaran visual tapi juga membantu siswa yang modalitas kinestetik. Penggunaan media yang sesuai dengan kondisi saat ini adalah media ICT. Media ini dapat memudahkan pembelajaran dan memusatkan konsentrasi siswa. Media ini harus dibuat menarik namun tetap efektif dan efisien. Salah satu media yang bisa digunakan media ICT yang berbentuk power point dengan menggunakan kosa kata dan gambargambar yang dikenali siswa dalam kehidupan nyatanya. Gambar yang ditampilkan diharapkan menarik minat siswa dalam belajar dan yang lebih utama adalah siswa merasa pelajaran itu bermanfaat untuk kehidupannya. Gambar tersebut diusahakan bersifat kekinian dan dikenal siswa serta menjadi topik pembicaraaan dalam masyarakat. Hal ini diharapkan dapat memberikan kesan mendalam bagi siswa karena gambar tersebut telah dikenal siswa sebelum siswa belajar tentang hal tersebut.

c. Perhatikan pengaturan kursi di kelas

Sebaiknya mengajar dengan susunan kursi yang dapat diubah. Namun jika kursi tidak dapat diubah maka tugas guru untuk menggubah lingkungan untuk memaksimalkan momen belajar siswa. Susunan kursi yang monoton dan selalu sama setiap harinya akan membuat siswa bosan, saat ini banyak sekali 
model susunan kursi yang bisa digunakan untuk menvariasikan suasana belajar. Susunan kursi ini juga bisa disesuaikan dengan materi pelajaran. Jika dalam praktek maharah kalam guru memerlukan empat orang pembicara maka susunan kursinya bisa diatur sesuai kebutuhan pembelajaran. Susunan kursi yang bisa dirubah dapat mengatasi kejenuhan dan kebosanan siswa, inilah salah satu hal yang menjadi tujuan $Q T$.

d. Perhatikan unsur organik.

Sebuah ruang kelas akan terasa nyaman jika didalamnya jika terdapat tanam-tanaman atau bunga yang dapat menyegarkan suasana dan menyegarkan mata siswa. Tanaman menghasilkan unsur oksigen yang bermanfaat untuk pernafasan bagi manusia, jadi jika di sebuah kelas ada tanaman dapat melegakan pernapasan siswa dan dapat menyegarkan pandangan mata siswa. Hal ini tentu dapat meningkatkan hasil pembelajaran siswa.

e. Berikan ruangan dengan wewangian

Beberapa penelitian menyebut-kan bahwa aroma terapi dapat menyegarkan otak. Hal ini dapat digunakan dalam proses pembelajaran hendaknya kelas itu terasa menyegarkan dengan adanya wangi-wangian yang mengharumkan ruangan. Aroma terapi dapat mengurangi stress, dan membangkitkan semangat dan menenangkan fikiran. Hal ini tentu akan sangat membantu siswa dalam pembelajaran.

\section{f. Penggunaan musik}

Musik berpengaruh pada siswa dan guru. Musik yang digunakan dapat merubah suasana hati. Penggunaan musik ini harus tepat, jangan sampai mengganggu proses penyampaian materi. Musik yang digunakan sebaiknya dengan ritme yang tenang sehingga tidak mengganggu aktivitas pembelajaran dan juga memilih lirik lagu yang sesuai dengan tema pembelajaran. Lebih baik memilih musik instrumentalia .

4. Perancangan pembelajaran yang dinamis.

$Q T$ memberikan beberapa kiat tentang cara menyesuaikan pembelajaran dengan masing-masing modalitas mengajar, memberikan strategi dan kiat tentang cara menjalin mitra dengan siswa, sehingga guru merancang pembelajaran bermula dari kelompok besar, dilanjutkan kelompok kecil dan diakhiri dengan perorangan.

\section{Dari Segi Konten/ Isi}

\section{Mengorkestrasi presentasi prima}

Kemampuan presentasi prima adalah kemampuan guru berkomunikasi dengan menekankan interaksi sesuai dengan rancangan pembelajaran. Guru berkomunikasi dengan siswa harus menyesuaikan pesan materi dengan modalitas utama para siswa. Guru harus menguasai prinsip-prinsip komunikasi visual, auditorial, dan kinestetik. Dalam berkomunikasi dengan siswa, maka guru harus menggunakan komunikasi yang efektif berupa:

a. Munculkan kesan. Kesan yang dimaksud adalah kesan terhadap apa yang dipelajari. Misalnya "siswa semua, materi pelajaran hari ini sangat menarik, belajarlah dengan baik agar kita semua dapat mengerti”'

b. Fokus, menurut hasil penelitian mutakhir otak manusia terdiri dari bermilyar-milyar sel yang masingmasing sel membuat jaringan tiap detik (Otak manusia mampu menerima lebih dari 10.000 informasi setiap detik Agus Nggermanto 2001: 37). Untuk menfokuskan perhatian siswa guru bisa mengatakan, "anakanak semua, coba lihat kesini" Saat ini siswa bisa diarahkan untuk melihat media pembelajaran ICT atau 
gambar-gambar yang dibuat oleh guru.

c. Inklusif, pembelajaran quantum dapat berlangsung ketika suasana seperti suasana kerja sama. Hal ini dapat diungkapkan guru dengan kalimat sebagai berikut "sekarang mari kita baca topik ini dengan baik"

d. Spesifik, seorang pendidik diarahkan untuk mengatakan sesuatu dengan kata-kata yang sedikit tetapi sampai pada tujuan yang dimaksud. Katakata yang terlalu banyak akan membuat siswa jenuh dan bosan.

e. Komunikasi non verbal, hal ini dapat berupa, keteladanan, pembiasaan, kontak mata, ekspresi wajah, performance, nada suara, senyuman dan sebagainya.

\section{Mengorkestrasi fasilitas elegan}

Mengorkestrasi fasilitas berarti memudahkan interaksi siswa dengan kurikulum. Ini berarti memudahkan partisipasi siswa dalam belajar sesuai dengan yang diinginkan dengan tingkat ketertarikan, minat, fokus dan partisipasi optimal. Disinilah peran guru bahasa Arab dalam mengembangkan kurikulum bahasa Arab sehingga siswa merasa kurikulum itu memang menarik dan dibutuhkan oleh siswa.

3. Mengorkestrasi ketrampilan belajar dan ketrampilan hidup.

Dalam $Q T$ ketrampilan belajar dapat membantu siswa mencapai tujuan belajar yang efektif dan efisien dengan tetap mempertahankan minat belajar. Kemampuan guru untuk memberikan dan membangkitkan ketrampilan belajar siswa dapat membuat tujuan pembelajaran dapat mudah dicapai.

\section{TUJUAN PEMBELAJARAN DE- NGAN MODEL $Q T$.}

QT memiliki beberapa tujuan diantaranya :1) Memberikan pengetahuan atau nilai kepada anak didik 2)
Memberikan pengalaman, 3) Meningkatkan partisipasi siswa melalui pengubahan keadaan, 4) Meningkatkan motivasi dan minat belajar, 5) Meningkatkan daya ingat siswa, 6) Meningkatkan rasa kebersamaan, 7) Meningkatkan daya dengar, 7) Meningkatkan kehalusan pribadi, 8) Memberikan ketrampilan proses atau metodologi dalam mencapai tujuan.

Hal ini dimaksudkan siswa tidak cukup hanya digiring untuk mengetahui materi pelajaran, melainkan mengapa dia harus tahu dan bagaimana cara mengetahuinya. Siswa diharapkan tidak hanya mengetahui hasil sesuatu tapi juga mengetahui cara memperoleh sesuatu. Dalam hal sebuah kata hikmah menyatakan biarkanlah seseorang kehilangan sesuatu tetapi tidak boleh kehilangan cara memperoleh sesuatu. Lebih dari itu perlu dijelaskan kepada siswa apa manfaat dari apa yang dipelajarinya untuk untuk kehidupannya saat ini dan yang akan datang. Siswa akan lebih termotivasi belajar ketika dia tahu apa yang dipelajarinya ada dalam realitas dan berguna bagi kehidupannya.

Dalam pembelajaran quantum guru harus memiliki kemampuan untuk mengorkestrasi konteks dan kontens. Konteks berkaitan dengan lingkungan pembelajaran, sedangkan konten berkaitan isi pembelajaran. Pembelajaran quantum merubah kelas menjadi komunitas belajar masyarakat mini yang setiap detilnya telah dirubah secara seksama untuk mendukung belajar optimal. Penelitian menunjukkan bahwa lingkungan sosial atau suasana kelas adalah penentu psikologis pertama yang mempengaruhi belajar akademis.

\section{REKONTRUKSI PEMBELAJARAN BAHASA ARAB DENGAN KE- RANGKA $Q T$}

$Q T$ salah satu alternatif pembaharuan model pembelajaran bahasa Arab. $Q T$ menyajikan petunjuk praktis dan spesifik untuk menciptakan lingkungan belajar yang efektif, rancangan 
pembelajaran, menyampaikan bahan pembelajaran dan bagaimana menyederhanakan proses belajar bahasa Arab sehingga memudahkan siswa belajar dan memahami Bahasa Arab.

Model $Q T$ menjadikan guru bahasa Arab sebagai aktor yang akan mempengaruhi kehidupan siswa. Seolah-olah seorang guru sedang memimpin konser di dalam ruang kelas. Guru harus memahami bahwa setiap siswa mempunyai karakter dan potensi masing-masing seperti seruling dan gitar yang mempunyai suara yang berbeda. Di antara siswa mungkin ada yang punya kemampuan dalam istima', kalam, qiraah, kitabah atau qawaid. Bagaimana setiap karakter dan potensi siswa dalam bahasa Arab dapat memiliki peran dan membawa sukses dalam belajar, hal ini merupakan inti dari pembelajaran $Q T$.

$Q T$ adalah model yang dijadikan penulis untuk merekonstruksi pembelajaran bahasa Arab yang dinamis dan mempunyai relevansi nyata dengan kehidupan siswa saat ini. Dan paling utama bagaimana pembelajaran bahasa Arab itu disenangi oleh siswa. Rekonstruksi pembelajaran bahasa Arab dengan QT menggunakan kerangka sebagai berikut; Tumbuhkan, Alami, Namai, Demonstrasikan, Ulangi dan Rayakan yang disingkat dengan istilah TANDUR.

Langkah Pertama, tumbuhkan; yang dimaksud di sini adalah guru terlebih dahulu menjelaskan bahwa bahasa Arab penting untuk dipelajari. Hal ini menumbuhkan motivasi siswa belajar bahasa Arab. Motivasi dalam diri siswa perlu ditumbuhkan karena motivasi semacam dorongan kebutuhan, keinginan siswa untuk mengetahui bahasa Arab. Jadi, Motivasi adalah energi dalam jiwa yang menggerakan manusia untuk melakukan perilaku tertentu guna mewujudkan tujuan yang sudah pasti.

Motivasi merupakan salah satu faktor yang menentukan keberhasilan belajar bahasa Arab. Tanpa adanya mo- tivasi, sulit bagi siswa untuk memperoleh keterampilan berbahasa sebagaimana yang diharapkan. Motivasi memiliki daya pemicu kemauan belajar yang sangat penting. Cara untuk meningkatkan motivasi adalah dengan menghubungkan bahan pengajaran dengan kebutuhan siswa dari segi pengalaman, minat, tata nilai, dan masa depannya.

Guru juga memberikan apersepsi yang cukup sehingga sejak awal kegiatan siswa telah termotivasi untuk belajar dan memahami Apakah Manfaatnya Bagi$\mathrm{Ku}$ (AMBAK) belajar bahasa Arab. Tumbuhkan suasana yang menyenangkan di hati siswa, dalam suasana relaks, tumbuhkan interaksi dengan siswa, masukkan ke alam pikiran mereka dan bawalah alam pikiran mereka ke alam pikiran kita, yakinkan siswa mengapa harus mempelajari bahasa Arab. Belajar bahasa Arab adalah suatu kebutuhan, bukan suatu keharusan. Bila minat dan motivasi belajar bahasa Arab sudah tumbuh maka setengah dari pekerjaan guru sudah dianggap sudah selesai. (Arsyad, 2005: 124)

Langkah kedua, alami; ciptakan dan datangkan pengalaman nyata yang dapat dimengerti semua siswa. Guru harus mengetahui cara terbaik agar siswa memahami informasinya. Upamanya guru memberikan teks latihan bahasa Arab yang kondisional dengan siswa. Model teks seperti ini akan lebih alami dan komunikatif yang akan menumbuhkan daya kreasi siswa. (Fuad Efendi, 2005: 118).

Langkah Ketiga, namai; dalam tahap ini, siswa dengan bantuan guru berusaha menemukan konsep atas pengalaman yang telah dilewati. Tahap penamaan memacu struktur kognitif siswa untuk memberikan identitas, menguatkan dan mendefinisikan apa yang dialaminya. Proses penamaan dibangun dengan pengetahuan awal dan keingintahuan siswa saat itu. Penamaan me- 
muaskan hasrat alami otak untuk memberikan identitas, mengurutkan, dan mendefinisikan. Penamaan adalah saatnya untuk mengajarkan konsep, keterampilan berpikir dan strategi belajar. Penamaan ini dalam bahasa Arab terlihat dalam mengajarkan qawaid yang dimulai dengan contoh-contoh berupa pengalaman siswa. Setelah mempelajari contohcontoh yang diberikan, siswa diarahkan menamakan contoh-contoh tersebut sesuai dengan qawaid. Dalam teknik pengajaran qawaid dinamakan dengan cara induktif (Fuad, 2005:85)

Langkah Keempat, demonstrasikan; setelah siswa mengalami belajar bahasa Arab, beri kesempatan kepada mereka untuk mendemonstrasikan kemampuannya berbahasa Arab, karena siswa akan mampu mengingat $90 \%$ jika siswa itu mendengar, melihat dan melakukan. Pelajaran bahasa Arab menuntut demonstrasi, yakni bagaimana siswa dapat menggunakan bahasa Arab itu dalam pembelajaran di kelas dan di luar kelas. Inti pada tahap ini adalah memberi kesempatan siswa untuk menunjukkan bahwa mereka tahu/bisa berbahasa Arab. Hal ini sekaligus memberi kesempatan siswa untuk menunjukkan tingkat pemahaman terhadap materi yang dipelajari. Dalam pembelajaran bahasa Arab dapat dicontohkan siswa yang telah berhasil menguasai beberapa diupayakan untuk mendemonstrasikan dalam kesempatan-kesempatan yang mereka alami. Untuk mendukung pelaksanaan demontrasi ini seorang guru bisa menggunakan media drama, cerita, atau sekedar percakapan-percakapan sederhana dalam kehidupan siswa di sekolah.

Langkah Kelima, ulangi; beri kesempatan kepada siswa untuk mengulangi apa yang telah mereka pelajari, sehingga setiap siswa merasakan langsung di mana kesulitan yang mereka alami. Pengulangan dapat memperkuat koneksi saraf dan menumbuhkan rasa " Aku tahu bahwa aku tahu ini!”. Jadi pengalaman harus dilakukan secara multimodalitas dan multikecerdasan, lebih baik dalam konteks yang berbeda dengan asalnya (permainan, pertunjukan drama, dan sebagainya). Pengulangan termasuk proses pematapan yang paling populer untuk meningkatkan dan memantapkan kemampuan dan keterampilan siswa berbahasa Arab. Pengulangan dapat menghadirkan kemudahan, karena ucapan yang pada kali pertama dianggap sulit oleh siswa, bila diulang beberapa kali, maka ucapan itu akan menjadi familiar dan mudah diungkapkan. Dalam hal ini Ari Ginanjar Agustian berargumen bahwa untuk membentuk sebuah karakter manusia unggul dibutuhkan mekanisme RMP (Repetitif Magic Power) atau pengulangan yang terus menerus. Dalam RMP ini, energi potensial yang maha dahsyat yang berada dalam diri setiap manusia diubah menjadi energi kinetik secara berulangulang, sehingga menghasilkan sebuah karakter manusia yang handal. Peng-

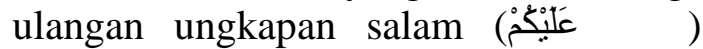
contohnya dalam bahasa Arab yang langsung diresponi oleh pendengar de-

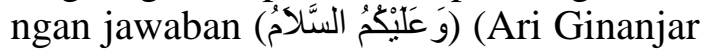
Agustian, 2003: .270). Dalam bahasa Arab unsur ini sangat penting, mengingat keterampilan bahasa yang baik hanya akan diperoleh dengan cara mengulang-ulang atau mendemonstrasikan pengetahuan bahasa yang telah dimiliki siswa.

Langkah Keenam, rayakan; sebagai respon pengakuan yang proporsional. Jika layak untuk dipelajari, maka layak pula hasil belajar tersebut untuk dirayakan. Merayakan akan memberikan rasa puas, senang terhadap apa yang telah dilakukan, diperbuat dan dihasilkan dengan menghormati usaha, ketekunan dan kesuksesan. Dalam pembelajaran quantum guru harus mampu mengorkestrasi kesuksesan belajar siswa. Dalam pembelajaran ini guru tidak semata-mata menterjemahkan kurikulum ke dalam strategi, metode, teknik dan langkah-langkah pembelajaran, melainkan juga menterjemahkan kebutuhan nyata siswa. 
Kerangka-kerangka di atas dilaksanakan secara terpadu dalam kegiatan pembelajaran bahasa Arab sehingga situasi kegiatan pembelajaran bahasa Arab menjadi sangat aktif, dinamis dan menyenangkan. Untuk terimplementasikan kerangka $Q T$ dalam pembelajaran bahasa Arab secara menarik dan menyenangkan, maka $Q T$ seharusnya dilaksanakan sesuai dengan prinsip-prinsip berikut ini:

Pertama, segalanya berbicara, maksudnya segala sesuatu yang dimulai dari lingkungan kelas, bahasa tubuh pengajar, penataan ruang, gambargambar dan slogan-slogan di dinding, sampai sikap guru, seperti kertas yang dibagikannya, rancangan pembelajaran, semuanya mengirimkan pesan tentang pembelajaran. Apapun yang digunakan dalam pembelajaran bahasa arab dapat bermanfaat sebagai media yang dapat memudahkan pemahaman siswa dalam mempelajari bahasa Arab. Pembelajaran Bahasa Arab sebagai sebuah bahasa yang asing bagi siswa membutuhkan banyak mufradat maka pembelajaran mufradat dapat dilaksanakan dengan prinsip quantum ini bahwa segala hal bisa berbicara dan menjadi media pembelajaran dan pengenalan mufradat bagi siswa. Jadi pembelajaran tidak hanya tergantung dari bahasa guru tapi juga segala hal lainnya yang bisa digunakan sebagai media.

Kedua, segalanya bertujuan, dengan maksud semua yang terjadi dalam proses pengubahan energi menjadi cahaya mempunyai tujuan. Usaha guru untuk mengubah kecerdasan siswa menjadi cahaya mempunyai tujuan agar siswa bisa belajar secara mandiri dan memiliki motivasi dalam belajar bahasa Arab. Siswa dikenalkan tujuan mereka mempelajari materi bahasa Arab sehingga mereka merasa pembelajaran bahasa Arab sesuatu yang bermanfaat. Pembelajaran bahasa Arab merupakan sebuah proses yang penting untuk mereka laksanakan. Dengan prinsip ini siswa merasa perlu menjalani proses belajar bahasa arab tanpa ada rasa keterpaksaan tapi justru merasa belajar bahasa arab itu sebagai sebuah kebutuhan.

Ketiga, pengalaman sebelum pemberian nama. Maksudnya proses pembelajaran paling baik terjadi jika siswa telah memiliki informasi sebelum mereka memperoleh materi bahasa arab, karena otak manusia berkembang yang akhirnya menggerakkan rasa ingin tahu. Hal ini dalam rencana pembelajaran dikenal dengan eksplorasi. Eksplorasi merupakan sebuah proses dimana siswa mencari dan memiliki teori, ilmu atau pengalaman nyata tentang pembelajaran sehingga hal ini akan sangat memudahkan siswa dalam proses pembelajaran selanjutnya. Dalam pembelajaran bahasa Arab saat ini materi bahasa arab banyak berkaitan dengan kehidupan nyata siswa karena itulah pembelajaran bahasa arab dimulai dengan mengingatkan siswa tentang pengetahuan yang dimilikinya yang berhubung dengan materi. Proses ini akan menimbulkan kesan mendalam bagi siswa karena pembelajaran bahasa Arab dimulai pengetahuan yang dimiliki siswa tentang teori tersebut dan siswa dapat mengaitkan teori tersebut dengan ilmu dan pengalaman nyatanya. Hal ini disebabkan otak manusia berkembang pesat dengan adanya stimulan yang kompleks yang selanjutnya menimbulkan rasa ingin tahu dan dapat memberikan kesan yang mendalam.

Ketiga, akui setiap usaha, maksudnya belajar mengandung resiko. Pada saat siswa mengambil langkah ini, mereka patut mendapat pengakuan atas kecakapan dan kepercayaan diri mereka. Penelitian mendukung konsep ini yang menyatakan bahwa kemampuan siswa meningkat karena pengakuan guru. (Boby de Potter, 2004: 29 ).

Keempat, jika layak dipelajari, maka layak pula dirayakan, dengan 
maksud. Perayaan memberikan umpan balik mengenai kemajuan dan meningkatkan asosiasi emosi positif dengan belajar. Cara tersebut jelas sangat berpengaruh dalam menambah rasa percaya diri siswa terhadap kemampuan dan potensinya dalam sebuah proses pembelajaran. Dalam pembelajaran bahasa Arab tak banyak ditemukan siswa yang langsung memiliki kemampuan berbahasa Arab yang baik, maka bentuk penghargaan yang diberikan kepada siswa selain mengakui kemampuannya juga merayakan keberhasilannya dalam pembelajaran. Sekecil apapun keberhasilan itu tetap patut untuk dirayakan. Perayaan ini dapat diberikan dengan pemberian tepuk tangan atau ucapan terima kasih (Syukran) guru atas pembelajaran yang berlangsung, hal ini jelas dapat membuat

\section{DAFTAR RUJUKAN}

Agus Nggermanto. 2001. Quantum Quotient Kecerdasan Quantum Bandung: Nuansa.

Agustian, Ari Ginanjar. 2003. Rahasia Sukses Membangkitkan ESQ Power, Sebuah Inner Journey melalui Al-Ihsan, Arga, Jakarta.

Bobbi DePorter et.al. 2004. Quantum Teaching, Mempraktekkan Quantum Learning di RuangRuang Kelas, terj. Ary Nilandari, Bandung: Kaifa.

Effendy, Fuad. 2005. Metodologi Pengajaran Bahasa Arab, Malang: Misykat.

Hartono dkk. 2008. Paikem Pembelajaran Aktif Inovatif Kreatif Efektif dan Menyenangka, Pekanbaru: Zanafa.

Hermawan, A.H dkk. 2008. Pengembangan Kurikulum dan Pembelajaran. Jakarta: Universitas Terbuka.

Ramayulis. 2008. Metodologi Pendidikan Agama Islam. Jakarta: Kalam Mulia. siswa merasa dihargai dan dapat lebih memotivasi siswa untuk belajar bahasa Arab.

\section{PENUTUP}

Dari uraian di atas dapatlah disimpulkan bahwa $Q T$ sangat cocok diterapkan dalam materi pelajaran bahasa Arab yang berkisar antara:, , , , , dan ,. Rekonstruksi pembelajaran bahasa Arab dengan kerangka $Q T$ terlihat suasana pembelajaran bahasa Arab yang dinamis, demokratis, menarik minat siswa belajar, juga dapat meningkatkan daya serap siswa secara dramatis asal suasana kelas yang ada telah dikondisikan seperti yang disarankan.

Salim, Muhammad. 1987. Al-Wasâ'il al-Ta'lîmiyyah Fî̀ Ta'lîm Al'Arabiyyah Wa Lughah Ajnabiyyah. Jakarta: Ma'had al'Ulum al-Islamiyyah $\mathrm{Wa}$ al'Arabiyyah Bi Indonesia.

Soetopo, Hendyat. 2005. Pendidikan dan Pembelajaran (Teori, Permasalahan, dan Praktek), Malang: UMM Press.

Sudarwan Danim. 2003. Agenda Pembaharuan Sistem Pendidikan, Yogyakarta: Pustaka Pelajar.

Udin Syaefudin Sa'ud. 2009. Inovasi Pendidikan, Bandung: Alfabeta.

Wahab, Muhbib Abdul. 2008. Efistemologi dan Metodologi Pembelajaran Bahasa Arab, UIN: Jakarta Press.

Win Wenger. 2001. Beyond Teaching \& Learning, Memadukan Quantum Teaching dan Learning. Terj. Ria Sirait Bandung: Nuansa. 

Indeks

bahasa....200, 201, 202, 203, 204, 206, 207, 208, 209, 210, 211

eksplorasi 210 guru 200, 201, 202, 203, 205, 206, 207, 208, 209, 210, 211

metode...........200, 201, 202, 203, 204, 209 motivasi .................................200, 208, 210 pembelajaran..200, 201, 202, 203, 204, 205, 206, 207, 208, 209, 210, 211

pendidikan .................... 200, 201, 202, 203

quantum teaching......................... 200, 203 siswa ......200, 201, 202, 203, 204, 205, 206, 207, 208, 209, 210, 211 